\title{
Stable isotope evidence for trophic overlap of sympatric Mexican Lake Chapala silversides (Teleostei: Atherinopsidae: Chirostoma spp.)
}

\author{
Norman Mercado-Silva ${ }^{1}$, John Lyons ${ }^{2}$, Rodrigo Moncayo-Estrada ${ }^{3}$, Pablo Gesundheit ${ }^{4}$, \\ Trevor J. Krabbenhoft ${ }^{5}$, Daniel L. Powell ${ }^{6,7}$ and Kyle R. Piller ${ }^{6}$
}

We explore the trophic role that a diverse sympatric group of fishes in the genus Chirostoma play in a large, shallow lake in central Mexico, Lake Chapala. We use $\delta^{13} \mathrm{C}$ and $\delta^{15} \mathrm{~N}$ stable isotope - based food web analyses to explore how they relate to other components of the Lake Chapala ecosystem. We find five Chirostoma species in top trophic levels of the Chapala food web compared to other fishes, relying on a combination of zooplankton, fish and benthic resources as energy sources. Food web metric analyses showed generally overlapping trophic niches for members of Chirostoma, especially in terms of $\delta^{13} \mathrm{C}$. However, $C$. jordani had lower mean $\delta^{15} \mathrm{~N}$ isotopic values than C. promelas. As a group, "pescados blancos" $(C$. sphyraena and C. promelas) also had higher $\delta^{15} \mathrm{~N}$ signatures than "charales" (C. consocium, C. jordani and C. labarcae) reflecting greater piscivory, but these differences were not strong for all food web metrics used. Trophic overlap among species of Chirostoma in Lake Chapala raises questions about the forces that might have led to a morphologically diverse but functionally similar and monophyletic group of species.

Exploramos el papel trófico de un diverso grupo de peces (género Chirostoma) que habita en simpatría en el Lago Chapala, México central. Utilizamos isótopos estables de $\delta^{13} \mathrm{C}$ y $\delta^{15} \mathrm{~N}$ para explorar la relación que guardan éstos peces con otros componentes del ecosistema. Encontramos a Chirostoma en niveles altos de la red trófica de Chapala, dependiendo energéticamente de zooplankton, peces y recursos del bentos. Análisis de parámetros de la red trófica demostraron traslape de nicho trófico para cinco miembros de Chirostoma, especialmente con relación a $\delta^{13} \mathrm{C}$. Sin embargo, C. jordani tuvo un menor valor promedio de $\delta^{15} \mathrm{~N}$ que C. promelas. Al ser analizados como grupo, los "pescados blancos" (C. sphyraena, C. promelas) tuvieron niveles promedio de $\delta^{15} \mathrm{~N}$ mayores que los "charales" (C. consocium, C. jordani, C. labarcae), indicando mayor ictiofagia, pero las diferencias no fueron significativas para todos los parámetros de red trófica utilizados. El traslape trófico entre las especies de Chirostoma en Chapala da origen a cuestionamientos acerca de las fuerzas que pueden haber intervenido en el surgimiento de un morfológicamente diverso pero funcionalmente similar grupo monofilético de peces.

Keywords: Charales, Food web, Menidini, Pescadoblanco, Shallow lake.

\section{Introduction}

Food web studies provide valuable insight into how energy flows across an ecosystem and about the structure of predator-prey relationships (Paine, 1980; Polis \& Winemiller, 1996). They can also provide key guidelines for ecosystem management, as they inform how species interact with other ecosystem components, and allow a synthesis of multiple ecological processes (Vander Zanden et al., 2003; Fry, 2006). In recent years, food web studies have benefited from the utilization of stable isotope techniques as tools for elucidating trophic structure and inferring pathways of energy/mass flow in food webs (Peterson \& Fry, 1987; Fry, 2006; Schmidt et al., 2007). Although studies have addressed the dietary content and trophic role of individual species in Mexican freshwater

\footnotetext{
${ }^{1}$ Departamento de Ecología y Recursos Naturales, Centro Universitario de la Costa Sur, Universidad de Guadalajara, Independencia Nacional 151, Autlán de Navarro, Jalisco, C. P. 04510. Mexico.normanmercado@yahoo.com

${ }^{2}$ University of Wisconsin Zoological Museum and Wisconsin Department of Natural Resources 2801, Progress Road, Madison, WI, 53718, USA.john.lyons@wisconsin.gov

${ }^{3}$ Centro Interdisciplinario de Ciencias Marinas, Instituto Politécnico Nacional, COFAA. Av. Instituto Politécnico Nacional s/n, Col. Playa Palo de Santa Rita, La Paz, B.C.S., México. C. P. 23096.rmoncayo@ipn.mx

${ }^{4}$ Department of Wildlife and Fisheries Sciences, Texas A\&M University, College Station, Texas, 77843, USA. pablo.gesundheit@ gmail.com

${ }^{5}$ Department of Biological Sciences, Wayne State University, 5047 Gullen Mall, Detroit, MI 48202, USA. krabbenhoft@wayne.edu

${ }^{6}$ Southeastern Louisiana University, Department of Biological Sciences, Hammond, LA 70402, USA. kyle.piller@selu.edu

${ }^{7}$ Department of Biology, Texas A\&M University, 3258 TAMU, College Station, TX 77843, USA. dpowell@bio.tamu.edu
} 
ecosystems (e.g., Navarrete et al., 1996; Moncayo-Estrada et al., 2007; Ramírez-Herrejón et al., 2013), those that use stable isotope techniques to describe food webs or food web interactions in freshwater ecosystems are relatively few (Mercado-Silva et al., 2009; Zambrano et al., 2010a, 2010b; Helmus et al., 2013).

Mexican lakes have been subject to numerous anthropogenic effects (e.g., pollution, habitat modifications, species introductions, overexploitation, among others) (Lyons et al., 2000; Hansen et al., 2006; López-Hernández et al., 2007; Trasande et al., 2010). Their fish fauna contains a relatively high number of imperiled species, and species that are of significant commercial and cultural importance (Lyons et al., 1998; MoncayoEstrada et al., 2012).

"Charales" and "pescados blancos", silversides in the genus Chirostoma (Atherinopsidae) are an important biological, cultural, and economic component of the lakes in Central Mexico, including Lake Chapala (Barbour, 1973a; Berlanga-Robles et al., 2002; Miller et al., 2005; Moncayo-Estrada et al., 2012). The clade includes up to 13 species that have been a resource since prehispanic times and continue to provide a commercial and subsistence fishery ( $\sim 1.2$ million metric tons were produced in 2012) (Berlanga-Robles et al., 2002; CONAPESCA, 2012; Bloom et al., 2013). Silversides are the most important native fish fishery in Chapala (Moncayo-Estrada et al., 2012). Lake Chapala is the largest lake in Mexico (area $\sim 1100 \mathrm{~km}^{2}$ ) and has been considered the largest shallow lake in the world (Limón \& Lind, 1990) (Fig. 1). Species of Chirostoma have been the focus of numerous investigations, including several studies related to diet (Moncayo-Estrada et al., 2007; Moncayo-Estrada et al., 2010; Moncayo-Estrada et al., 2011b), exploitation and fisheries (Berlanga-Robles et al., 2002), and phylogenetic relationships (Barbour, 1973b; Bloom et al., 2009, 2012, 2013). Based on morphometry and diet studies Lake Chapala "pescados blancos" such as C. sphyraena and $C$. promelas are considered primarily piscivorous, while "charales" such as $C$. consocium, $C$. jordani and C. labarcae are thought to be primarily zooplanktivores (Barbour, 1973a; Miller et al., 2005). However, there are known differences among sympatric species in the relative contribution of zooplankton (e.g., calanoid and cyclopoid copepods, cladocerans), insects or fish to their diets (Wurtsbaugh \& Li, 1985; Peck et al., 2003; MoncayoEstrada et al., 2010). For example, Moncayo-Estrada et al. (2011b) reported significant diet niche overlap among three sympatric species of Chirostoma in Lake Chapala when the lake suffered water volume reductions, but niche separation when volumes were reestablished. Further, fish morphometry (i.e., head length, oral gape, and gill raker structure) has been related to differences in prey classes (Moncayo-Estrada et al., 2010).

While the trophic attributes of Chirostoma have been the focus of several studies, little information exists about how these fish relate from a trophic perspective to other fish species in the lake, and the role that they play in the overall Lake Chapala food web. Thus, our objectives are to 1) document the trophic position of species of Chirostoma in relation to other fish species and food web components in Lake Chapala based on stable isotope data, and 2) test for $\mathrm{C}$ and $\mathrm{N}$ isotopic trophic differences among species of Chirostoma spp. in Lake Chapala., expecting differences between "pescados blancos" and "charales". In this effort we consider whether stable isotope - derived findings correspond to those that could be inferred from morphology (head shape analyses) and published diet studies.

\section{Material and Methods}

Study site. Located in West Central Mexico in the States of Michoacán and Jalisco (Fig. 1), Lake Chapala is a mesotrophic warm, shallow (maximum depth $\sim 10 \mathrm{~m}$; mean depth $\sim 4.5 \mathrm{~m}$ ), tropical lake that has experienced severe water fluctuations in the last decades (in millions of cubic meters: 2,428 in 1990; 4,202 in 1995; 1,989 in 2000; 5,072 in 2005; 5,678 in 2010) (Comisión Estatal del Agua de Jalisco (CEA), 2013). Water volume fluctuations in Lake Chapala result from a combination of natural processes, particularly climatic variations, as well as human activities mainly related with agricultural and urban development in the watershed (Aparicio, 2001). In addition to water fluctuations, the Lake Chapala ecosystem faces numerous threats from point and non-point pollution, fishery exploitation, and the introduction of non-native species (Trujillo-Cardenas et al., 2010; Moncayo-Estrada et al., 2012). Lake Chapala's main tributary is the Lerma River (draining a large region in Central Mexico) from the East and its outlet is the Santiago River to the North (Fig. 1).

The fish fauna of Lake Chapala harbors 26 species including eight species in the central Mexico endemic genus Chirostoma (Atherinopsidae), the central Mexico endemic subfamily Goodeinae, and native and endemic cyprinid fish species, as well as non-indigenous species, such as common carp Cyprinus carpio (Cyprinidae) and tilapia Oreochromis niloticus (Cichlidae) (MoncayoEstrada \& Buelna-Osben, 2001).

At the time of sampling the lake had the following physical-chemical characteristics (obtained using a Hydrolab DS5 Datasond ${ }^{\circledR}$; samples taken at $1 \mathrm{~m}$ max. below water surface): Dissolved oxygen $(\mathrm{mg} / \mathrm{L})=5.79$ (mean) $( \pm 0.08)(\mathrm{SD})$; dissolved oxygen saturation $(\%)$ $=77( \pm 0.01)$; water temperature $\left({ }^{\circ} \mathrm{C}\right)=19.58( \pm 0.63)$; conductivity $(\mathrm{mS} / \mathrm{cm})=0.86( \pm 0.01)$; salinity $(\mathrm{ppt})=0.44$ $( \pm 0.006)$; turbidity $(\mathrm{NTU})=45( \pm 28.99)$; total dissolved solids $(\mathrm{g} / \mathrm{L})=0.55( \pm 0.008) ; \mathrm{pH}=9.41( \pm 0.04)$; ammonia concentration $(\mathrm{mg} / \mathrm{L}-\mathrm{N})=4.58( \pm 1.26)$; nitrates $(\mathrm{mg} / \mathrm{L}-\mathrm{N})$ $=9.41( \pm 2.60)$. Our collections took place at sites with a maximum depth of $6.78 \mathrm{~m}$, and a minimum depth of 0.30 $\mathrm{m}$, in mud to rock substrates. 


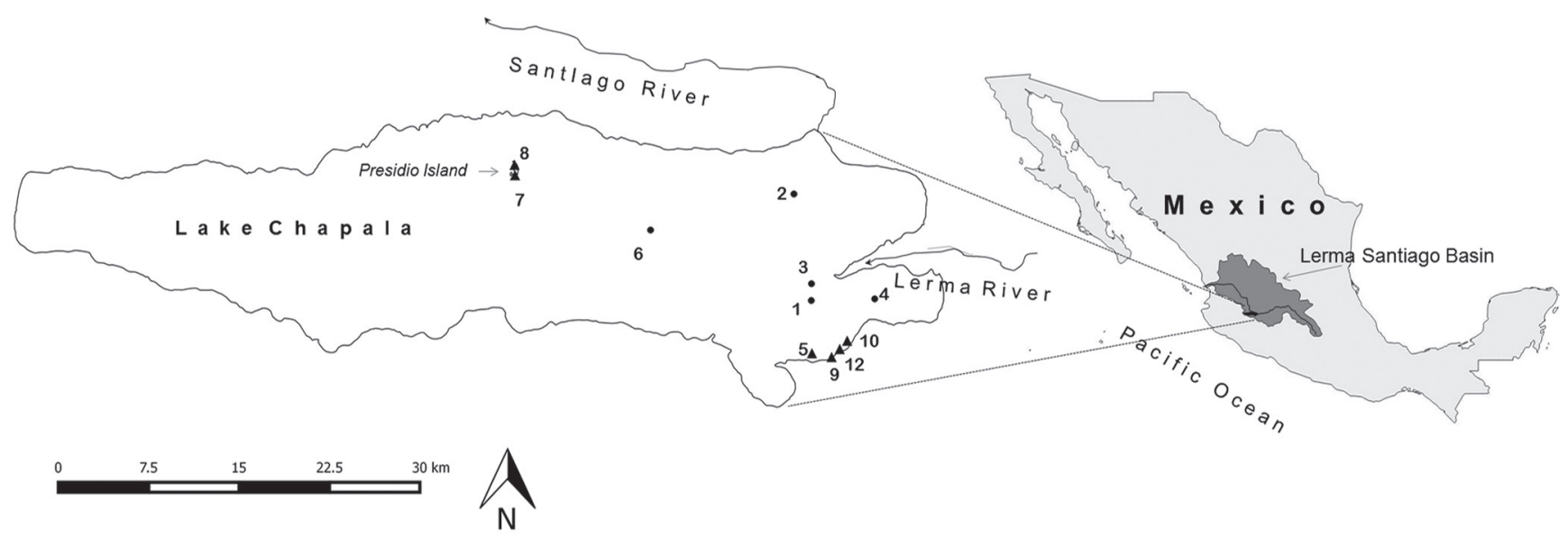

Fig. 1. Lake Chapala in West-Central Mexico with eleven sampling sites identified (sites represented by circles were located $>1 \mathrm{~km}$ from the shoreline, sites represented by triangles were located $<1 \mathrm{~km}$ from the shoreline). The Lerma - Santiago River Basin is shown as reference. The Lerma (inlet) and Santiago (outlet) rivers are identified. See methods section for a description of sites, including site 11, not shown in the image.

Sampling. Twelve sites in areas near $(<1 \mathrm{~km})$ and far $(>1$ $\mathrm{km}$ ) from the shoreline of Lake Chapala were visited over a two day period during November 2011. All sampling efforts took place during daylight hours. Fish, zooplankton and benthic invertebrates were not captured at all sites. Sites $1,2,3,4$ and 6 were far from shore $(1-7 \mathrm{~km})$ and sites 5 and 7-12 were near to shore $(0.05-0.66 \mathrm{~km})$ (sites 7 and 8 were located close to Presidio Island, in the northern central portion of the lake). We sampled sites at different distances from shore to test for differences in stable isotope signatures related to potentially different sources of food existing close and far from the shoreline. All linear distances to shore were calculated based on site coordinates using measuring tools in Google Earth (C) (with satellite images from October 2011 and February 2013).

Our sampling efforts targeted adult Chirostoma spp., but adult individuals belonging to other species were also captured opportunistically. Fish samples were collected using an experimental trawl net (length $10 \mathrm{~m}$; depth $2 \mathrm{~m}$; mouth width $3 \mathrm{~m}$; mesh size $12 \mathrm{~mm}$ ), and by hand from traps used by local fishermen. Captured individuals were identified in the field, sacrificed, and kept in ice for further processing. From each sample we kept up to 6 individuals per Chirostoma species ranging from 28-104 mm total length. For other species, we kept all captured individuals. Fish identification was done to species level for all individuals in genera Chirostoma, Chapalichthys (Goodeidae), Lepomis (Characidae) and Goodea (Goodeidae), but we only identified to genus for individuals in Oreochromis sp. and Poecilia sp. (Poeciliidae). One freshly captured specimen of Chirostoma sphyraena was provided by local fishermen; we were unable to locate the exact location of the site where the fish was captured using GPS coordinates (site 11), but based on the fishermen's account, the site was located close to the southern shore of the lake.
To obtain data on the diversity of food resources available to Lake Chapala fishes we obtained zooplankton and benthic invertebrate samples. At sites 1-7 we collected zooplankton samples using a conical plankton net $(0.5 \mathrm{~m}$ ring diameter and $243 \mu \mathrm{m}$ mesh). Zooplankton samples were taken from the water surface by horizontally dragging the net behind the sampling boat. Once a sufficient amount of zooplankton was collected, it was bagged and placed on ice. At sites 1, 2, 3, 5, 8, and 12, benthic invertebrates were collected by hand, using small-mesh nets, or as by-catch in the trawl (see Appendix). No fish were captured at sites 8 and 12. Benthic invertebrate samples were also placed on ice prior to processing. Benthic invertebrates were identified to the lowest taxon possible; we did not divide zooplankton into separate taxonomic subgroups.

Sample processing and stable isotope analysis. We followed Vander Zanden et al. (1999, 2003) for sample processing. Approximately $1 \mathrm{~g}$ of dorsal muscle tissue was obtained from fish individuals for stable isotope analysis. Zooplankton samples from each site were processed in bulk. Benthic invertebrates were processed whole when an individual invertebrate's size was sufficient to obtain at least $2 \mathrm{mg}$ (dry weight); if individuals were not large enough (i.e., Hyallela and ephemeropterans), we pooled all available individuals from each site. Fish muscle tissue, zooplankton samples and benthic individuals were dried, pulverized and analyzed for $\delta^{15} \mathrm{~N}$ and $\delta^{13} \mathrm{C}$ stable isotopes. Stable isotope analysis was performed at the University of New Mexico Department of Earth and Planetary Sciences. Two percent of all samples were processed in duplicate (mean standard error was $0.13 \%$ for $\mathrm{C}$ and $0.25 \%$ for $\mathrm{N}$ ). Stable isotope analyses and quantitative tests were carried out based on 154 fish, 6 zooplankton, and 12 benthic invertebrate samples (see Appendix 1). 
We estimated food web structure for Lake Chapala using carbon and nitrogen stable isotope ratios $\left(\delta^{13} \mathrm{C}\right.$ and $\left.\delta^{15} \mathrm{~N}\right)$. Stable isotope ratios are expressed in delta $(\delta)$ notation, which is defined as the parts per thousand (\%) deviation from standard material (Pee Dee Belemnite for ${ }^{13} \mathrm{C}$ and atmospheric air for $\left.{ }^{15} \mathrm{~N}\right) ; \delta^{13} \mathrm{C}$ or $\delta^{15} \mathrm{~N}=([$ Rsample/ Rstandard] - 1) 1000 , where $\mathrm{R}={ }^{13} \mathrm{C} /{ }^{12} \mathrm{C}$ or ${ }^{15} \mathrm{~N} /{ }^{14} \mathrm{~N} . \delta^{13} \mathrm{C}$ is conserved from prey to predator, and is used to trace energy sources for a food web (Hecky \& Hesslein, 1995; Vander Zanden et al., 1999). Since there is a 3-4\% increase in $\delta^{15} \mathrm{~N}$ from prey to predator, it can be used to estimate differences in the trophic level that a species occupies in the food web (Vander Zanden \& Rasmussen, 1999).

We used correlation analyses (Pearson's r) to test for relationships in $\delta^{15} \mathrm{~N}$ and $\delta^{13} \mathrm{C}$ values among different sized fish in a species. We found no trend in isotopic values related to fish size. We also tested (ANOVA) for $\delta^{15} \mathrm{~N}$ and $\delta^{13} \mathrm{C}$ value differences among fish from different sites. We found no significant site-related differences for individuals in a species. Since we did not find size or site related differences among individuals in each species, we carried out all other food web analyses (see below) using the isotopic values for all the individuals of a species regardless of size or site of provenience.

We also tested for differences (two-sample $t$-tests) in the range of isotopic values for Chirostoma spp. depending on the distance to shore of a given collection site. The range of $\delta^{15} \mathrm{~N}$ valuesin a sample has been used as surrogate for food web length. The range of $\delta^{13} \mathrm{C}$ in a sample can be used to infer the variety of sources of carbon to a given food web component. To do this we grouped sites as "far" from or "near" to shore (see above definition), and then compared $\delta^{15} \mathrm{~N}$ and $\delta^{13} \mathrm{C}$ values for individual Chirostoma species and for all Chirostoma species combined. We also calculated the coefficient of variation for $\delta^{15} \mathrm{~N}$ and $\delta^{13} \mathrm{C}$ values for each Chirostoma species.

We used three different analytical approaches to study the trophic role that Chirostoma have in the Lake Chapala food web. We first created a bivariate plot of the mean $( \pm 1$ $\mathrm{SE})$ isotopic values $\left(\delta^{13} \mathrm{C}\right.$ on the $\mathrm{x}$-axis; $\delta^{15} \mathrm{~N}$ on the $\mathrm{y}$-axis) for all individuals in a species or group (including grouped benthic invertebrates, zooplankton and non-atherinopsid fishes). This plot provided a first indication of the relative position of individual species of Chirostoma spp. in Lake Chapala. We then focused on Chirostoma spp., using methods in Schmidt et al. (2007) and Turner et al. (2010) to investigate isotopic differences among species within the genus, and between "pescados blancos" and "charales".

We used methods in Turner et al. (2010) to carry out two separate data analyses. First we compared stable isotope values among four Chirostoma species collected (only 2 C. sphyraena were captured and were excluded from this analysis). Then we compared stable isotope values between Chirostoma species in the "pescado blanco" group (Miller et al., 2005) (C. sphyraena, C. promelas), and Chirostoma species in the "charales" group $(C$. consocium,
C. jordani, C. labarcae). Turner et al. (2010) developed tests for differences between the centroids (see below) of two samples or differences between samples in four of the dispersion measures described by Layman et al. (2007). These differences are potential indicators of differences in (trophic) niche position and breadth, and resource use, and can be used as means to evaluate ontogenetic changes in resource use or movement of organisms between isotopically distinct habitats (Layman et al., 2007; Turner et al., 2010). We first tested for differences in the mean isotopic (MD) value for each species or species group. Then we assessed the mean distance to centroids (MDC) (a centroid being the mean $\delta^{13} \mathrm{C}$ and $\delta^{15} \mathrm{~N}$ for all individuals in a species) for each species or group. MDC is a metric of isotopic value dispersion. Next, we assessed metric "mean nearest neighbor" (MNN), which measures the data point density for a species or group. Finally, we tested for the roundness of the clump of data (isotopic values) using metric "eccentricity" (ECC) (see Turner et al., 2010, for a discussion of these metrics). For each metric we tested whether the observed difference for two species or groups (pairwise comparisons) was significantly (at $\alpha=0.05$ ) greater than 0 (zero), based on a residual randomization procedure with 999 permutations. In each test, the null hypothesis was that there was no difference in metrics between species being compared. All tests were followed by Bonferroni corrections for multiple statistical comparisons. All tests were carried out using R (http://www.r-project.org/), with code for conducting statistical tests of stable isotope data from Turner et al. (2010) (Ecological Archives E091-157-S1).

Stable isotope analytical methods proposed by Schmidt et al. (2007) make use of circular statistics and hypothesis tests to quantitatively compare several food web attributes. Commonly used in behavioral ecology, circular statistics is an area of mathematics concerned with the analysis of angles ranging from 0 to $360^{\circ}$, or equivalently, from 0 to $2 \pi$ radians (Batschelet, 1981). These procedures have been used to calculate the magnitude and direction of change in food web space for species over time or across space (Schmidt et al., 2007). In our case, we used these methods to compare the inter-specific food web space of species of Chirostoma and Chirostoma groups based on their $\delta^{13} \mathrm{C}$ and $\delta^{15} \mathrm{~N}$ values, which were used as coordinates $(\mathrm{x}, \mathrm{y})$. The null hypothesis was that there would be no differences in food web space among species of Chirostoma or Chirostoma groups. To carry out our analysis we followed the appropriate mathematical protocols for angular data (Batschelet, 1981). We converted spatial coordinates (x, y, as described in the food web plot in Fig. 2) for each Chirostoma individual into angles and vector magnitudes. Changes in isotopic food web space were measured by comparing the position of each individual (and the mean angle for all individuals in a species) to the centroid for all Chirostoma species. By taking the average isotopic value across all individuals of Chirostoma we made the assumption, as do all food web studies, that the mean is representative of the entire 
population of individuals. Thus, our analyses focused on whether the values of a given Chirostoma species or group were concentrated in a certain direction from the overall mean coordinate (the origin) for all Chirostoma species, and on whether there were differences in the angular distributions of pairs of Chirostoma species or groups. Rayleigh's and Watson-William's tests were used in the circular statistical analyses. Rayleigh's test for circular uniformity was used to assess whether the distribution of mean angles of direction of a species departed nonrandomly from uniformity. The null hypothesis for this test states that a species population is uniformly distributed, or in other words, movements occur in all directions with equal frequency or have no mean direction. In the context of this analysis, Rayleigh's test examines whether mean angular change $(\theta)$ in food web space for each Chirostoma species or species group is nonrandom. The WatsonWilliam's two sample test of homogeneity was used to compare the angular distribution of each pair of species of Chirostoma (or species groups) and determine if their mean angles differed significantly. The null hypothesis for this test was that the mean angle of movement from the centroid for a species pair (or group pair) was the same. We carried out a Watson William's par-wise comparison between each species (or group) pair, and also an overall test among all species of Chirostoma. All circular statistic tests were performed using Oriana 4.0 (Rockware, Inc., Golden, Colorado, USA).

Head morphometry analysis. Morphometric features have been related to the trophic role of fish (Gatz, 1979a, 1979b; Kassam et al., 2004). To explore a possible relationship between trophic differences among Chapala Chirostoma spp. and their head morphology we used geometric morphometry techniques. We quantified head shape for the same five species of Chirostoma analyzed via stable isotopes. Morphometric analyses were based on preserved museum specimens captured in Lake Chapala, not live specimens captured in the field. Museum specimens were obtained from lots at Tulane University, the University of Michigan Museum of Zoology and Southeastern Louisiana State University. Photographs were taken from the left side of the head from each individual. Twelve landmarks were digitized for each individual using Tpsdig2 (Rohlf, 2005). Procrustes superimposition was used to remove position, orientation, and size biases for each species separately. Canonical variates (CV) analyses and generation of deformation grids were performed using MorphoJ $1.05 \mathrm{f}$ (Klingenberg, 2011).

\section{Results}

We found no significant differences among all Chirostoma spp. or for individual Chirostoma species $\delta^{15} \mathrm{~N}$ and $\delta^{13} \mathrm{C}$ values between samples taken from sites close to or far from the shoreline of Lake Chapala. Coefficients of variation of $\delta^{13} \mathrm{C}$ were similar for C. consocium, C. jordani and $C$. labarcae (2.42, 2.23, and 2.04, respectively). These were not significantly higher than that for $C$. promelas (1.32), or lower than that for C. sphyraena (5.09). Coefficients of variation of $\delta^{15} \mathrm{~N}$ for $C$. consocium, $C$. jordani, C. labarcae and C. promelas $(3.38,2.63,4.23$, and 4.96 , respectively) were non-significantly lower than that for C. sphyraena (9.40).

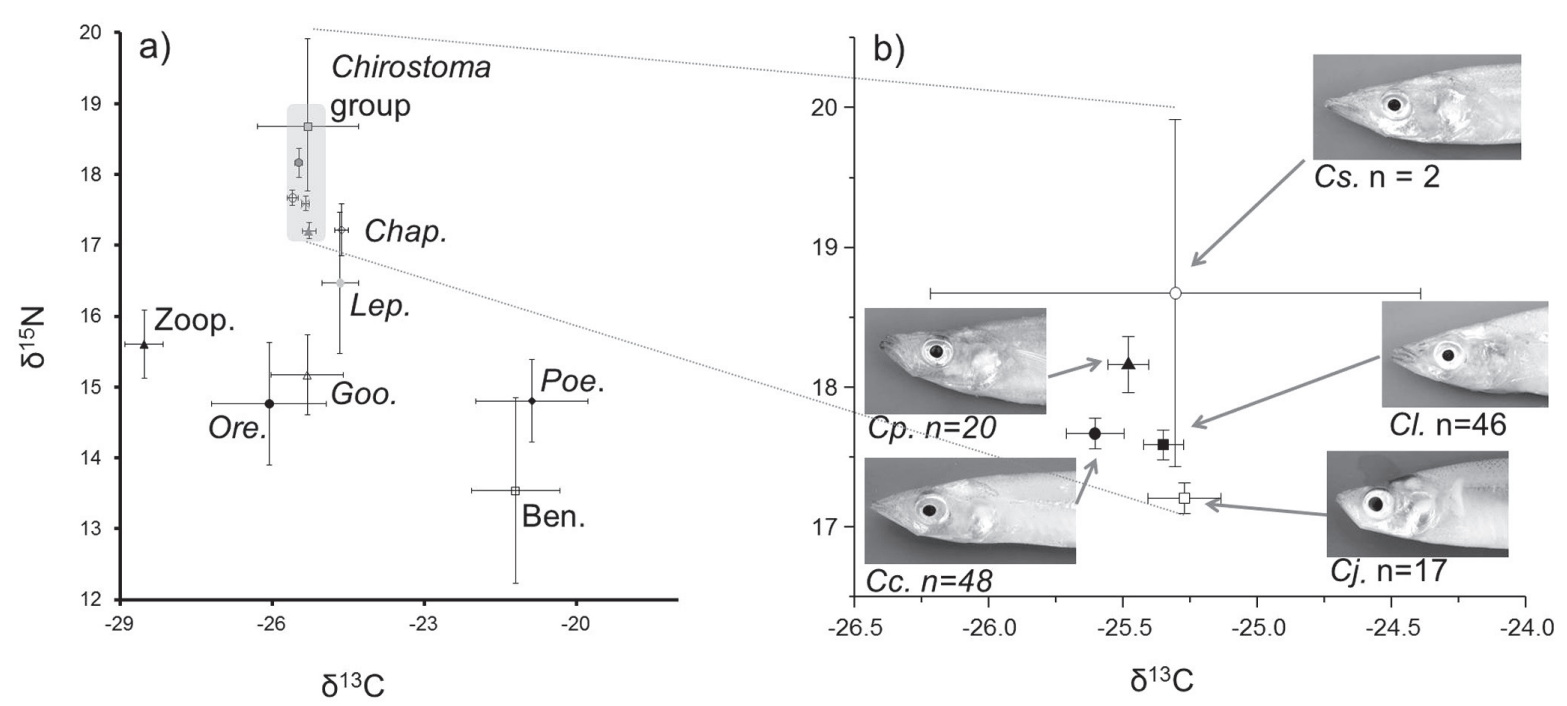

Fig. 2. a) Lake Chapala food web plot resulting from the analysis of $\delta^{13} \mathrm{C}$ and $\delta^{15} \mathrm{~N}$ stable isotope values. Values for both plots are mean $\delta^{15} \mathrm{~N}$ and $\delta^{13} \mathrm{C}( \pm 1 \mathrm{SE})$. Shaded area corresponds to species in gen. Chirostoma, which is plotted in detail in b) In note jaw morphology differences among silverside species (n indicates the number of specimens in each species for which isotopic values were determined). Acronyms for both figures: Chapalichthys encaustus $=$ Chap.; Lepomis macrochirus $=$ Lep.; Goodea atripinnis $=$ Goo.; Oreochromis sp. $=$ Ore.; Zooplankton $=$ Zoop.; Poecilia sp. $=$ Poe.; benthic invertebrates $=$ Ben.; C. sphyraena $=\mathrm{Cs} ; C$. labarcae $=\mathrm{Cl} ; C$. consocium $=\mathrm{Cc}$; . promelas $=\mathrm{Cp} ; C$. jordani $=\mathrm{Cj}$. 
Chirostoma species occupy the highest position in the Lake Chapala food web relative to other fishes (based on relative $\delta^{15} \mathrm{~N}$ values) and food web components (Fig. 2a). However, based on $\delta^{15} \mathrm{~N}$ values, they overlap with native Chapalichthys encaustus and nonnative Lepomis macrochirus. Lower trophic levels are occupied by native Goodea atripinnis and non-natives Poecilia sp. and Oreochromis sp. Our samples showed well separated benthic and pelagic (for $\delta^{13} \mathrm{C}<-23 \%$ ) food web components. Benthic invertebrates and Poecilia sp. had the most enriched $\delta^{13} \mathrm{C}$ values of all food web components. Zooplankton had the least enriched $\delta^{13} \mathrm{C}$ values for all food web components analyzed. Chirostoma and other fish species, except for Poecilia sp., had average $\delta^{13} \mathrm{C}$ values between -24 and $-26 \%$, suggesting reliance on a combination of benthic invertebrates (or other benthic resources not considered here) and pelagic resources (i.e., zooplankton). Among Chirostoma species, C. sphyraena had the highest $\delta^{15} \mathrm{~N}$ values, followed by $C$. promelas, $C$. labarcae and C. consocium; $C$. jordani had the lowest average $\delta^{15} \mathrm{~N}$ values in the genus. Average $\delta^{13} \mathrm{C}$ values were very similar among species of Chirostoma.

Similarities in $\delta^{13} \mathrm{C}$ and $\delta^{15} \mathrm{~N}$ values among members of Chirostoma were confirmed by food web metrics $\mathrm{MD}, \mathrm{MDC}, \mathrm{MNN}$ and ECC, and pairwise tests of these metrics among the species. The only statistically significant pair-wise Bonferroni-corrected comparison (at $\alpha=0.05$ ) resulted for metric MD between $C$. jordani and C. promelas; $C$. jordani had lower mean $\delta^{15} \mathrm{~N}$ isotopic values than $C$. promelas. Charales and pescados blancos (considered as groups of species) were significantly different by metrics MD ( $\mathrm{p}=0.001)$ and ECC $(0.004)$, but not by metrics MDC or MNN (both p-values $>0.05$ ). Most of the difference in MD was in the $\delta^{15} \mathrm{~N}$ dimension, with higher values for pescados blancos $(18.21 \%$ ) than charales $(17.56 \%)$. Mean values in the $\delta^{13} \mathrm{C}$ dimension were similar between pescados blancos and charales (-25.46\% and $-25.44 \%$, respectively).

Rayleigh's tests were not statistically significant for most Chirostoma species, except for $C$. jordani (Rayleigh's test $Z=3.17, p=0.04)$. The mean vector $(\mu)$ for this species was $203.68^{\circ}$, with length $(\mathrm{r})=0.432$ and circular SD $=74.25^{\circ}$ (Fig. 3a). Specifically, C. jordani individuals tended to have lower $\delta^{15} \mathrm{~N}$ values than the average Chirostoma, and also showed enriched $\delta^{13} \mathrm{C}$ values, relative to the average Chirostoma in Lake Chapala. Pair-wise Watson - William's F tests among Chirostoma species were all non-statistically significant; the differences between mean angles of direction for different species were all similar. When grouped as charales or pescados blancos, both groups had nonsignificant results for Rayleigh's tests ( $p>0.05)$. Pairwise Watson - William's F test for these groups showed significant differences among groups $(\mathrm{F}=32.24, \mathrm{p}=$ $\left.8.38^{-8}\right)$; the mean angles of direction for the groups were different (Fig. 3b).

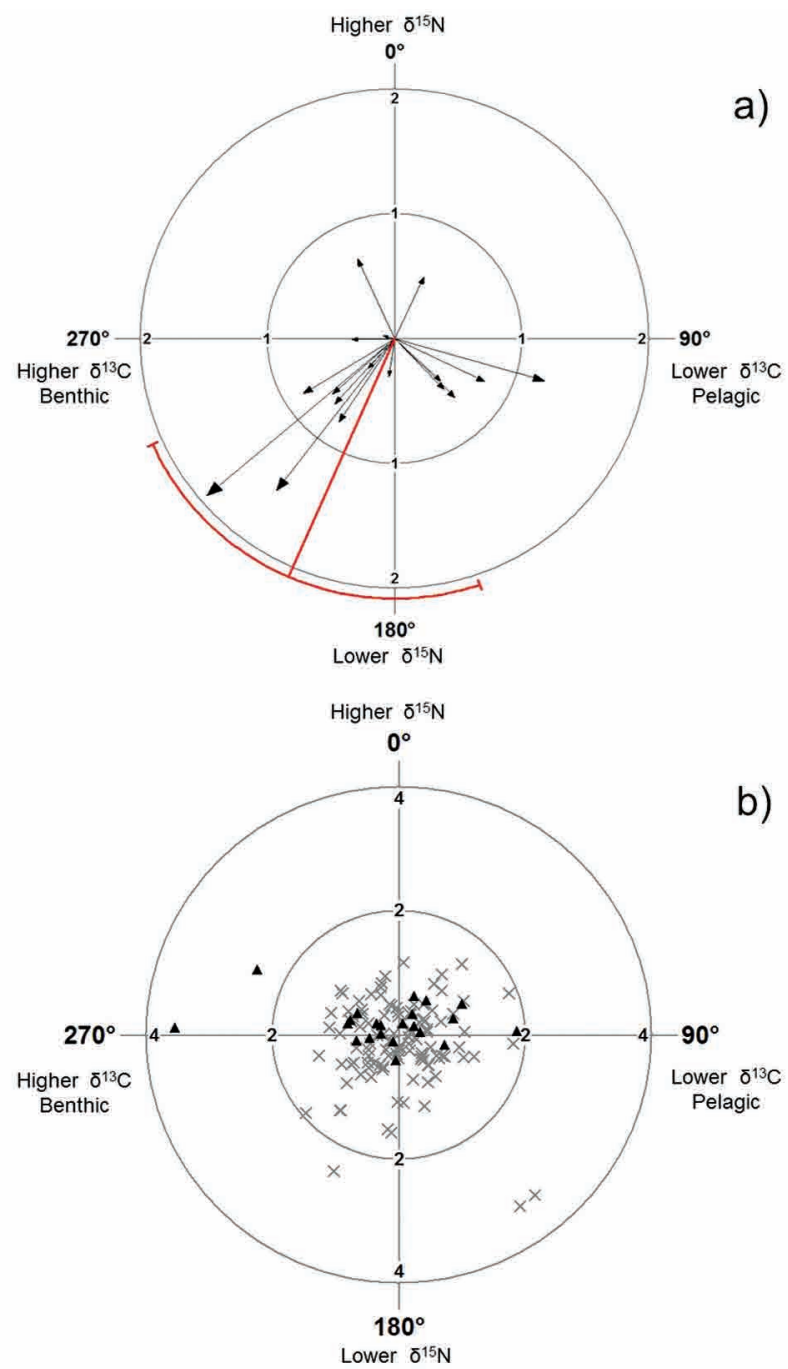

Fig. 3. a) Arrow diagram for the distribution of angles $(\theta)$ for Chirostoma jordani in Lake Chapala, Mexico. Angles are calculated from $\delta^{15} \mathrm{~N}$ and $\delta^{13} \mathrm{C}$ values for $C$. jordani individuals. The red line is the mean vector of movement (in isotopic food web space) for the species; the curved thicker line on the rim indicates the $95 \%$ confidence interval around the mean vector of movement. b) Angle scatter diagram of isotopic distribution of the "charales" group (including $C$. jordani, C. labarcae and C. consocium) (crosses) and the "pescados blancos" group (including $C$. sphyraena and $C$. promelas) (triangles).

Significant differences in head shape were recovered for the five species of Chirostoma (Fig. 4) resulting in three groups separated along CV2 in morphospace. Chirostoma jordani and C. consocium overlapped substantially in morphospace possessing a short snout and a deep bodied head in the posterior region. Chirostoma promelas and $C$. sphyraena also overlapped in head shape with both species possessing elongated heads and snouts. Chirostoma labarcae occupied a unique position in morphospace with a head shape intermediate between the other two groups. 


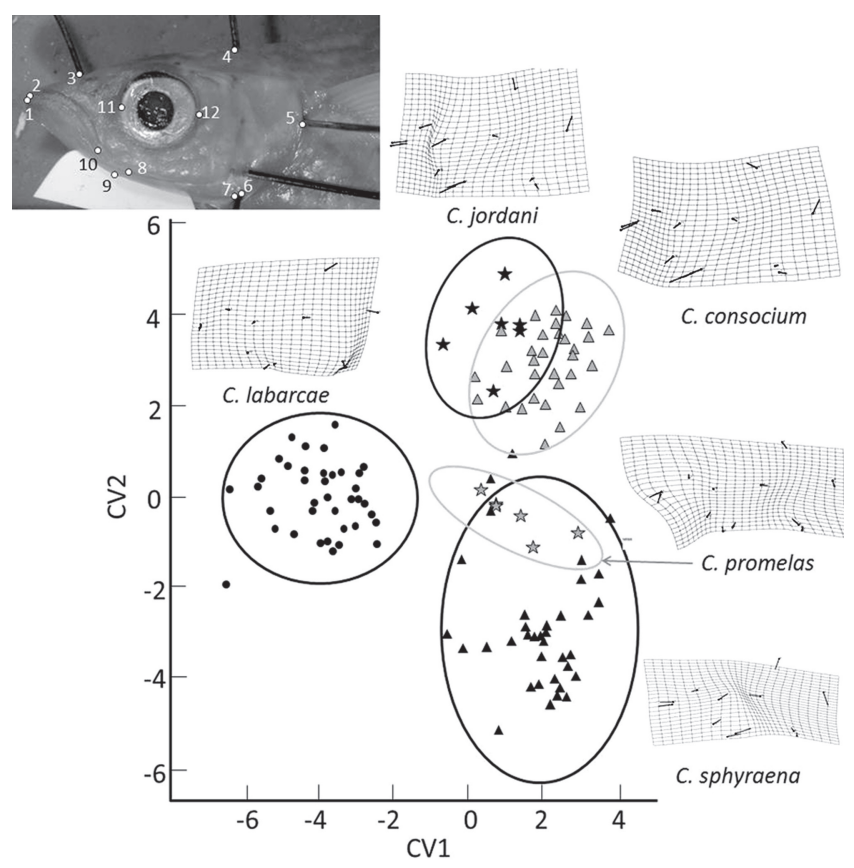

Fig. 4. Canonical variate analysis (CVA) plot and deformation grids for twelve head landmarks (shown in inset photograph) of five species of Chirostoma from Lake Chapala, Mexico. Deformation grids exaggerated 3x times to better visualize shape differences. Analysis based on museum specimens from lots at Tulane University (TU), the University of Michigan Museum of Zoology (UMMZ) and Southeastern Louisiana State University (SLU): $C$. consocium: UMMZ 240102 ( $\mathrm{n}=30)$; C. jordani: SLU 5031 $(\mathrm{n}=2), 5033(\mathrm{n}=2), 6678(\mathrm{n}=2) ;$ C. labarcae: SLU 6679 $(\mathrm{n}=23)$, TU $31966(\mathrm{n}=15) ;$ C. promelas: TU $31987(\mathrm{n}=1)$, $40843(\mathrm{n}=5)$, and C. sphyraena: SLU $5032(\mathrm{n}=1)$, SLU $6676(n=6), 6841(n=1)$. Analysis carried out using tps DIG V.2 (SUNY, Stonybrook University), Procrustes fit and data alignment by principle axes. CVA carried out using MorphoJ v105a.

\section{Discussion}

Stable isotope studies can provide unique perspectives of food web function in freshwater ecosystems. Our work, a first stable isotope-based analysis of the food web structure for Chapala, has revealed intriguing aspects of food web dynamics in the lake. The species of Chirostoma examined in this study sit at the top of the Lake Chapala food web. While they rely on zooplankton and fish as their main source of energy, our stable isotope data suggests that they may be also consuming food items with enriched $\delta^{13} \mathrm{C}$ values, relative to $\delta^{13} \mathrm{C}$ values for zooplankton as a group. Moncayo-Estrada et al. (2011b) found zooplankton in genera Bosmina, Diaphanosoma, Daphnia, Ceriodaphnia, Diaptomus and Cyclops to be the main food items for $C$. labarcae, C. consocium and C. jordani. Given the known diet for species of Chirostoma, we expected these fish to have similar $\delta^{13} \mathrm{C}$ values to those of zooplankton. However, values among these groups differed by approximately $4 \%$ in the carbon dimension. Thus, it is possible that Chapala charales, while mainly zooplanktivorous, are also feeding on benthic items (i.e., invertebrates among periphyton, insect larvae), which had enriched $\delta^{13} \mathrm{C}$ values relative to the pelagic zooplankton we analyzed. This would be a situation analogous to that of species of Chirostoma in Lake Pátzcuaro (Michoacán, Mexico), which are known to feed on both pelagic zooplankton, and other food resources throughout the water column, including the benthos and insect larvae (Rauda \& García de León, 1989; Soria-Barreto \& PauloMaya, 2005; Moncayo-Estrada et al., 2010; García de León et al., 2014). Higher eccentricity (ECC) in pescados blancos could suggest a higher plasticity in resource use than is available for charales. Higher mean isotopic (MD) values for pescados blancos over charales, driven by values in $\delta^{15} \mathrm{~N}$, reflect the known dominance of fish in pescado blanco diets (Barbour, 1973a; Miller et al., 2005). Among-group differences from circular statistics analyses also suggest differential resource reliance for charales and pescados blancos, with the latter higher in the trophic web of Lake Chapala (i.e., with diets dominated by fish). However, while dispersion measure tests (Turner et al., 2010) suggest strong differences among groups, we note that our results may be heavily influenced by outliers in either group, and that there is still strong overlap among groups. Similarly, results from Watson-Williams tests should be carefully interpreted. Pescados blancos had higher $\delta^{15} \mathrm{~N}$ and more benthic $\delta^{13} \mathrm{C}$ values compared to charales (Fig. 3b); but data dispersion for both groups was rather uniform (e.g., data for a given group were not concentrated into a specific angle).

Bi-plot qualitative comparisons did not completely separate Chirostoma from native Chapalichthys encaustus and invasive Lepomis macrochirus (bluegill). While data specific to Lake Chapala are lacking, food habits for $L$. macrochirus are well known and include zooplankton, macroinvertebrates and fish (Olson et al., 2003). The smallsized $(<100 \mathrm{~mm})$ L. macrochirus that we analyzed are known to eat mainly zooplankton and macroinvertebrates; this could explain why they did not differ appreciably from silversides in Chapala. Large L. macrochirus will potentially have a higher trophic level than most fish in the lake, as piscivory increases with increasing size for the species. While teeth and gut morphology suggest that $C$. encaustus is herbivorous (Miller et al., 2005), it has also been suggested that they incorporate insects onto their diets (GWG, 2013). Our work, which places C. encaustus close to silversides and L. macrochirus in isotopic space, suggests that reliance of $C$. encaustus on macroinvertebrates could be more extensive than suggested by morphology. Like most goodeids, C. encaustus is probably a plastic species, being able to exploit a variety of resources. It also suggests that potential competition could be occurring among Chirostoma, C. encaustus, and non-native bluegill. However, competition could be reduced by differences in prey availability (i.e., zooplankton assemblage and densities) and 
predator species differential distribution in the lake (i.e., $C$. labarcae vs. C. jordani) (Welker et al., 1994; Pangle et al., 2007; Moncayo-Estrada et al., 2011a). Goodea atripinnis and Oreochromis sp., fishes located relatively low in the Lake Chapala food web, are known omnivores (Bruton \& Boltt, 1975; Miller et al., 2005). Goodea atripinnis are known to feed on green algae and water plants, but can also consume microcrustaceans and mollusks (Miller et al., 2005). Introduced populations of tilapia are primarily herbivores, but will also feed on insects, zooplankton, phytoplankton, vascular plants, and larval/juvenile fishes (Hensley \& Courtenay, 1980). The relatively low trophic position that these species occupy in the Lake Chapala food web reflect these dietary preferences. Fishes in the genus Poecilia will largely consume green algae, fine detritus and diatoms (Scharnweber et al., 2011; Ramírez-Herrejón et al., 2013), which are also food for a wide array of benthic invertebrates. This overlap is evidenced by the relatively low trophic level, and relatively enriched values of $\delta \mathrm{C}^{13}$ that both groups have in Lake Chapala.

Sympatric speciation events in lake fishes have been linked to differences in the use of available prey items (Barluenga et al., 2006). Utilization of diverse food groups by ancestral members of a species flock within a lake can lead, via food specialization over time, to morphological differentiation and ultimately reproductive isolation (Barluenga et al., 2006; Wagner et al., 2009). Chirostoma species in Lake Chapala exhibit diverse jaw morphologies and body shapes that suggest different feeding habits among the eight species present in the lake. Evidence from gut content analyses has uncovered differences among species (Moncayo-Estrada et al., 2010, 2011b). In some cases, such differences have been attributed to changing Lake Chapala water levels (Moncayo-Estrada et al., 2011a), but other, fine scale studies have suggested preference of a species for a given zooplanktonic group (i.e., diet dominance of cladocerans vs. calanoid or cyclopoid copepods) (MoncayoEstrada et al., 2007). While charales and pescados blancos did separate in isotopic space, we were generally unable to differentiate species of Chirostoma based on stable isotope data. One potential cause for this finding could be our lack of separation of zooplankton samples into various subgroups. Different zooplankton components could show different stable isotope values, and could perhaps uncover finer scale energy flow paths in the Chapala food web. Alternatively, this finding could suggest that even when small scale differences in diet could be occurring among various Chirostoma species, these may not be significant when observed in the context of lake-wide food web dynamics. Further, diet studies describe what is eaten in a particular moment in time, while musclederived stable isotope information integrates what has been assimilated into biomass over several months. Thus from a functional perspective, all Chapala Chirostoma species analyzed could be sharing a similar role. Further, given that we found no differences among sites it is possible that our results are applicable to the entire lake.
Chirostoma jordani was the only species that separated from the overall Chirostoma group in circular statistics analyses. The species had enriched $\delta^{13} \mathrm{C}$ and lower $\delta^{15} \mathrm{~N}$ values, relative to the other Chirostoma species. This suggests that $C$. jordani is utilizing food resources that are of more benthic provenience, and may be feeding on food items with lower trophic levels. These differences have also been described in dietary studies. Moncayo-Estrada et al. (2010) found small cladocerans (e.g., Bosmina) to be the main diet for $C$. jordani; while $C$. consocium and C. labarcae predominantly preyed on copepods and large sized cladocerans (e.g. Daphnia). Lower $\delta^{15} \mathrm{~N}$ values for $C$. jordani could be due to these dietary differences. Chirostoma jordani is also known to occupy shallower areas close to the lakeshore than other species and dominates in the Lerma River inflow zone (Moncayo-Estrada et al., 2011a). Figure 2 suggests that $C$. sphyraena could have a relatively high trophic position among analyzed Chirostoma. Chirostoma sphyraena, the second largest species of the genus, are piscivorous especially at adult stages (Barbour, 1973a; Moncayo-Estrada et al., 2003; Miller et al., 2005). Unfortunately, the low number of specimens captured for this species prevents us from drawing stronger conclusions about its relative position. However, when grouped with $C$. promelas, a piscivore in adult stages that also consumes benthic organisms and the smallest of pescados blancos (Moncayo-Estrada et al., 2003), they do separate from charales analyzed.

Similar to our findings based on stable isotope data, independent gut length data analyses based on a small number of museum specimens failed to uncover differences in relative gut length among Lake Chapala species of Chirostoma, despite substantial differences in head shape (Fig. 4). Relative gut length (based on measurements for one museum specimen) of $0.51,0.49,0.43,0.49$ and 0.52 , were obtained for C. consocium, C. jordani, C. sphyraena, $C$. labarcae and $C$. promelas, respectively. Although admittedly based on a single individual, this provides an intriguing contrast with studies that have found that trends in gut length can correlate with different diet compositions in ecosystems where sympatric speciation has been robustly documented (e.g., Wagner et al., 2009). This finding opens up the questions of 1) what are the driving forces behind Chirostoma speciation in Chapala?, 2) are historical speciation forces similar or even present in today's Lake Chapala?, and 3) can we interpret these forces in light of the many changes that have occurred in the lake?

Morphological specializations for sympatric species of Chirostoma in Chapala arose over many generations, starting in the Plio-Pleistocene (Miller et al., 2005). Three morphological groups were recovered in head shape analyses depicted in Fig. 4; these groups correspond to 1) pescados blancos $C$. promelas $-C$. sphyraena, and two groups of charales 2) C. labarcae, and 3) $C$. jordani $-C$ consocium. We expected to recover a strong relationship between morphology and trophic specialization, as has 
been recovered in previous studies of fishes (Kassam et al., 2003a, 2003b). Lack of such relationship suggests that other factors including species specific habitats (which are unknown for most species of Chirostoma), predatory influences, environmental changes, and the young age of the silverside radiation may be responsible for the decoupling of morphological and trophic-based differentiation for Lake Chapala assemblage of silversides. Natural (i.e., lake size changes, basin separation) and anthropogenic factors (i.e., species introductions, pollution) have changed lake conditions and selective pressures under which speciation arose. It is possible that current Lake Chapala conditions no longer provide the selective forces that originally led to morphological differentiation and speciation in Chirostoma. Morphological diversification can thus be a reflection of past conditions in the system, whereas stable isotope and diet evidence represent current "unnatural" conditions. We hypothesize that prior to major human modifications of Lake Chapala, the food web of Chapala may have had distinct isotope and diet differences among species that more accurately correlated with morphology. With the catastrophic changes that have occurred in the lake, the food web is likely very different and the role of Chirostoma in the web may have become more homogenous. Impacts to the Lake Chapala food web have been profound; nonnative tilapia, Poecilia sp., and Lepomis macrochirus have become abundant, whereas formerly common species such as another pescado blanco (C. lucius), native catfish (Ictalurus dugesi, Ictaluridae), popoche (Algansea popoche, Cyprinidae), sardina (Yuriria chapalae, Cyprinidae), and several goodeids are now rare and could in some cases be functionally extinct (Moncayo-Estrada et al., 2012). Invasive water hyacinth has also become pervasive and it is likely that exotic zooplankton and benthos have entered the lake. Lake Chapala food web alterations have occurred at all trophic levels.

We recognize that a number of limitations to our study prevent us from reaching overarching conclusions about the food webs of Lake Chapala and the trophic differences among Chirostoma in the lake. First, we base our analyses on just a few benthic invertebrate and zooplankton samples, which may not represent the entire faunal diversity in Chapala. We also do not incorporate samples from all species of fish in the lake, or the diversity of habitat types or ontogenic stages available for these species. Our collections occurred throughout a short time period in the dry season, preventing us from drawing information about how Chapala food webs are structured over longer periods of time (i.e., seasons, years). Fish dietary composition is known to change among seasons and it would be valuable to expand stable isotope collection over a longer timeframe. We also did not incorporate data from several other species of Goodeidae, Ictaluridae, Atherinopsidae, Cichlidae or Petromyzontidae known to the lake (Moncayo-Estrada \& Buelna-Osben, 2001). In spite of these limitations, we feel our data and analysis can provide 1) a valuable insight into how various biotic components in Lake Chapala interact, and 2) new evidence to aid in our understanding about how a strongly monophyletic group has evolved.

The Lake Chapala ecosystem will continue to undergo fluctuations of water levels, levels of water pollution, and fishery pressure, among several other factors (MoncayoEstrada et al., 2012). These fluctuations will be the result of various environmental pressures and restoration efforts ongoing in the Lerma River basin and the lake per se. They will continue to affect the fish community and the general ecosystem. Our work adds to the general understanding of how the fish community may respond to ecosystem change. The conservation of Lake Chapala as a center of adaptive radiation for fishes and other groups, as a waterbody that controls regional climate, and as an important resource for several human communities (Moncayo-Estrada \& BuelnaOsben, 2001; Hansen \& van Afferden, 2001; SandovalMoreno \& Hernández-García, 2013) depends on our awareness of those responses.

\section{Acknowledgements}

Research supported by U.S. National Science Foundation grant \#: DEB 0918073 to KRP. Field activities supported by CUCSur - Universidad de Guadalajara and Centro Interdisciplinario de Investigación para el Desarrollo Integral Regional, Instituto Politécnico Nacional, Unidad Michoacán. Special thanks to Viorel Atudorei (Dept. of Earth and Planetary Sciences, U. of New Mexico) for assistance in stable isotope analyses; also to Hank Bart and Nelson Rios (TU), and William Fink and Douglas Nelson (UMMZ) for the loan of specimens for geometric morphometric analysis. Jesus Morales Castellanos assisted with field collections. R. Moncayo-Estrada is supported by the Comisión de Operación y Fomento de Actividades Académicas (COFAA) and Estímulo al Desempeño Académico (EDI).

\section{References}

Aparicio, J. 2001. Hydrology of the watershed. Pp. 3-31. In: Hansen, A. M. \& M. van Afferden (Eds.). The LermaChapala watershed evaluation and management. New York, Kluwer Academic.

Barbour, C. D. 1973a. A biogeographical history of Chirostoma (Pisces: Atherinidae): a species flock form the Mexican Plateau. Copeia, 3: 533-556.

Barbour, C. D. 1973b. The systematics and evolution of the genus Chirostoma Swainson (Pisces, Atherinidae). Tulane Studies in Zoology and Botany, 18: 97-136.

Barluenga, M., K. N. Stölting, W. Salzburger, M. Muschick \& A. Meyer. 2006. Sympatric speciation in Nicaraguan crater lake cichlid fish. Nature, 439: 719-723.

Batschelet, E., 1981. Circular statistics in biology. London, New York, Academic Press. 371p.

Berlanga-Robles, C. A., J. Madrid-Vera \& A. Ruiz-Luna. 2002. Fish abundance and trophic structure from the commercial catch in Lake Patzcuaro, Mexico. Hydrobiologia, 467: $117-122$ 
Bloom, D. D., K. R. Piller, J. Lyons, N. Mercado-Silva \& M. Medina-Nava. 2009. Systematics and biogeography of the silverside tribe Menidiini (Teleostomi:Atherinopsidae) based on the mitochondrial ND2 gene. Copeia, 2: 408-417.

Bloom, D. D., P. J. Unmack, A. E. Gosztonyi, K. R. Piller \& N. R. Lovejoy. 2012. It's a family matter: molecular phylogenetics of Atheriniformes and the polyphyly of the surf silversides (Family: Notocheiridae). Molecular Phylogenetics and Evolution, 62: 1025-2030.

Bloom, D. D., J. T. Weir, K. R. Piller \& N. R. Lovejoy. 2013. Do freshwater fishes diversify faster than marine fishes? A test using state-dependent diversification analyses and molecular phylogenetics of new world silversides (Atherinopsidae). Evolution, 67: 2040-2057.

Bruton, M. N. \& R. E. Boltt. 1975. Aspects of the biology of Tilapia mossambica Peters (Pisces: Cichlidae) in a natural freshwater lake (Lake Sibaya, South Africa). Journal of Fish Biology, 7: 423-445.

Comisión Estatal del Agua de Jalisco (CEA). 2013. Niveles máximos y mínimos del lago de Chapala. Available from: http://www.ceajalisco.gob.mx/chapala/niveles.html. (Accessed 19 Dec. 2013).

CONAPESCA, 2012. (Comisión Nacional de Acuacultura y Pesca). Consulta específica por especie año 2012.. Available from: http://www.conapesca.sagarpa.gob.mx/wb/cona/ consulta_especifica_por_produccion. (Accessed 17 Dec. 2013).

Fry, B. 2006. Stable isotope ecology. New York, NY, Springer, $308 \mathrm{p}$.

García de León, F. J., J. P. Ramírez-Herrejón, R. GarcíaOrtega \& D. A. Hendrickson. 2014. Foraging patterns of four sympatric species of silversides (Atheriniformes: Atherinopsidae) in Lago de Pátzcuaro, Central Mexico. Research Journal of the Costa Rican Distance Education University, 6: 127-139.

Gatz, A. J. 1979a. Community organization in fishes as indicated by morphological features. Ecology, 60: 711-718.

Gatz, A. J. 1979b. Ecological morphology of freshwater stream fishes. Tulane Studies in Zoology and Botany, 21: 91-124.

Goodeid Working group (GWG). 2013. Chapalichthys encaustus: Available from http://www.goodeidworkinggroup.com/ Chapalichthys-encaustus (Accessed Dec. 11, 2013).

Hansen, A. M. \& M. van Afferden, 2001 (Eds.). The LermaChapala Watershed: evaluation and management. New York, Kluwer Academic, 385p.

Hansen, A. M., A. Villa-Navia \& M. van Afferden. 2006. Scenarios of the distribution of lead in water, sediments and bacteria of lake Chapala, Mexico. Ingeniería Hidráulica En México, 21: 43-56.

Hecky, R. E. \& R. H. Hesslein. 1995. Contributions of benthic algae to lake food webs as revealed by stable isotope analysis. Journal of the North American Benthological Society, 14: 631-653.

Helmus, M. R., N. Mercado-Silva \& M. J. Vander Zanden. 2013. Subsidies to predators, apparent competition and the phylogenetic structure of prey communities. Oecologia, 173: 997-1007.

Hensley, D. A. \& J. W. R. Courtenay. 1980. Tilapia mossambica (Peters). Pp. 774. In: Lee, D. S., C. R. Gilbert, C. H. Hocutt, R. E. Jenkins, D. E. McAllister \& J. R. Stauffer Jr. (Eds.). Atlas of North American Freshwater Fishes. Raleigh, NC. North Carolina State Museum of Natural History.
Kassam, D. D., D. C. Adams, A. J. D. Ambali \& K. Yamaoka. 2003a. Body shape variation in relation to resource partitioning within cichlid trophic guilds coexisting along the rocky shore of Lake Malawi Animal Biology, 53: 59-70.

Kassam, D. D., D. C. Adams, M. Hori \& K. Yamaoka. 2003b. Morphometric analysis on ecomorphologically equivalent cichlid species from lake Malawi and Tanganyika. Journal of Zoology, London, 260: 153-157.

Kassam, D. D., D. C. Adams \& K. Yamaoka. 2004. Functional significance of variation in trophic morphology within feeding microhabitat-differentiated cichlid species in Lake Malawi. Animal Biology, 54: 77-90.

Klingenberg, C. P. 2011. MorphoJ: an integrated software package for geometric morphometrics. Molecular Ecology Resources, 11: 353-357.

Layman, C. A., D. A. Arrington, C. G. Montana \& D. M. Post. 2007. Can stable isotope ratios provide for community-wide measures of trophic structure? Ecology, 88: 42-48.

Limón, J. G. \& O. T. Lind. 1990. The management of Lake Chapala (Mexico): considerations after significant changes in the water regime. Lake and Reservoir Management, 6: $61-70$.

López-Hernández, M., M. G. Ramos-Espinosa \& J. CarranzaFraser. 2007. Multimetric analyses for assessing pollution in the Lerma River and Chapala lake, Mexico. Hidrobiologica, 17(1 suplemento): 17-30.

Lyons, J., G.-H. Altagracia, E. Díaz-Pardo, E. Soto-Galera, M. Medina-Nava \& R. Pineda López. 2000. Development of a preliminary index of biotic integrity (IBI) based on fish assemblages to assess ecosystem condition in the lakes of Central Mexico. Hydrobiologia, 418: 57-72.

Lyons, J., G. González-Hernández, E. Soto-Galera \& M. Guzmán-Arroyo. 1998. Decline of freshwater fishes and fisheries in selected drainages of West Central Mexico. Fisheries, 23: 10-18.

Mercado-Silva, N., M. R. Helmus \& M. J. Vander Zanden. 2009. The effects of impoundment and non-native species on a river foodweb in Mexico's central plateau. River Research and Applications, 25: 1090-1108.

Miller, R. R., W. L. Minckley \& S. M. Norris, 2005. Freshwater fishes of México. Chicago. University of Chicago Press. $490 \mathrm{p}$.

Moncayo-Estrada, R. \& H. R. Buelna-Osben. c2001. Fish fauna of Lake Chapala. Pp. 215-242. In: Hansen, A. M. \& M. van Afferden (Eds.). The Lerma-Chapala Watershed evaluation and management. New York. Kluwer Academic/Plenum Publishers.

Moncayo-Estrada, R., C. Escalera-Gallardo \& O. T. Lind. 2011a. Spatial patterns of zooplanktivore Chirostoma species (Atherinopsidae) during water-level fluctuation in the shallow tropical Lake Chapala, Mexico: seasonal and interannual analysis. Neotropical Ichthyology, 9: 815-824.

Moncayo-Estrada, R., C. Escalera-Gallardo, C. Lopez \& O. T. Lind. 2007. Diet of Chirostoma lucius (Pisces: Atherinomorpha): seasonal trophic spectrum and ontogeny of piscivory. Southwestern Naturalist, 52: 229-233.

Moncayo-Estrada, R., C. Escalera-Gallardo \& V. SeguraGarcía. 2003. Los pescados blancos del lago de Chapala. Características generales. Pp. 57-78. In: Rojas-Carrillo, P. M. \& D. Fuentes-Castellanos (Eds.). Historia y advances del cultivo de pescado blanco. Instituto Nacional de la PescaSAGARPA, Mexico City, 57-78. 
Moncayo-Estrada, R., O. T. Lind \& C. Escalera-Gallardo. 2010. Trophic partitioning of sympatric zooplanktivorous silverside in a tropical shallow lake: fish morphometry and diet composition. Copeia, 3: 431-436.

Moncayo-Estrada, R., O. T. Lind \& C. Escalera-Gallardo. 2011b. Trophic interactions among sympatric zooplanktivorous fish species in volume change conditions in a large, shallow, tropical lake. Neotropical Ichthyology, 9: 169-176.

Moncayo-Estrada, R., J. Lyons, C. Escalera-Gallardo \& O. T. Lind. 2012. Long-term change in the biotic integrity of a shallow tropical lake: a decadal analysis of the Lake Chapala fish community. Lake and Reservoir Management, 28: 92-104.

Navarrete, N. A., R. Sanchez \& M. L. Rojas. 1996. Selección del zooplancton por el charal Chirostoma jordani (Atheriniformes: Atherinidae). Revista de Biologia Tropical, 44: 757-761.

Olson, N. W., C. P. Paukert, D. W. Willis \& J. A. Klammer. 2003. Prey selection and diets of bluegill Lepomis macrochirus with differing population characteristics in two Nebraska natural lakes. Fisheries Management and Ecology, 10: 31-40.

Paine, R. T. 1980. Food webs: linkage, interaction strength and community infrastructure. Journal of Animal Ecology, 49: 666-685.

Pangle, K. L., S. D. Peacor \& O. E. Johannsson. 2007. Large nonlethal effects of an invasive invertebrate predator on zooplankton population growth rate. Ecology, 88: 402-412.

Peck, M. A., R. S. Katersky, L. M. Menard \& D. A. Bengtson. 2003. The effect of body size on food consumption, absorption efficiency, respiration, and ammonia excretion by the inland silverside, Menidia beryllina (Cope) (Osteichthyes: Atherinidae). Journal of Applied Ichthyology, 19: 195-201.

Peterson, B. J. \& B. Fry. 1987. Stable isotopes in ecosystem studies. Annual Review of Ecology and Systematics, 18: 293320 .

Polis, G. A. \& K. O. Winemiller (Eds.). 1996. Food webs: integration of patterns \& dynamics., New York, Chapman and Hall.

Ramírez-Herrejón, J. P., L. S. Castañeda-Sam, R. MoncayoEstrada, J. Caraveo-Patiño \& E. F. Balart. 2013. Trophic ecology of the exotic Lerma livebearer Poeciliopsis infans (Cyprinodontiformes: Poeciliidae) in the Lago de Pátzcuaro, Central Mexico. Revista de Biologia Tropical (International Journal of Tropical Biology), 61: 1289-1300.

Rauda, O. J. \& F. J. García de León. 1989. Análisis trófico de Chirostoma patzcuaro Meek 1902 (Pisces: Atherinidae) del Lago de Pátzcuaro, Mich., Méx. Boletín Coordinación de Investigación Científica, 13: 23-29.

Rohlf, F. J., 2005. tpsDig2. In: Department of Ecology and Evolution. State University of New York at Stony Brook. Available from: http://life.bio.sunysb.edu/morph/softdataacq.html.

Sandoval-Moreno, A. \& A. Hernández-García. 2013. Cambios socioambientales y crisis de los pescadores en el lago de Chapala, en México. Ambiente y Desarrollo, 17: 13-27.

Scharnweber, K., M. Plath, K. O. Winemiller \& M. Tobler. 2011. Dietary niche overlap in sympatric asexual and sexual livebearing fishes Poecilia spp. Journal of Fish Biology, 79: 1760-1773.
Schmidt, S. N., J. D. Olden, C. T. Solomon \& M. J. Vander Zanden. 2007. Quantitative approaches to the analysis of stable isotope food web data. Ecology, 88: 2793-2802.

Soria-Barreto, M. \& J. Paulo-Maya. 2005. Morfometría comparada del aparato mandibular en especies de Chirostoma (Atheriniformes: Atherinopsidae) del Lago de Pátzcuaro, Michoacán, México. Hidrobiológica, 15: 161-168.

Trasande, L., J. E. Cortes, P. J. Landrigan, M. I. Abercrombie, R. F. Bopp \& E. Cifuentes. 2010. Methylmercury exposure in a subsistence fishing community in Lake Chapala, Mexico: an ecological approach. Environmental Health, 9: 1-10.

Trujillo-Cárdenas, J. L., N. P. Saucedo-Torres, P. F. Z. del Valle, N. Rios-Donato, E. Mendizábal \& S. Gómez-Salazar. 2010. Speciation and sources of toxic metals in sediments of Lake Chapala, Mexico. Journal of the Mexican Chemical Society, 54: 79-87.

Turner, T. F., M. L. Collyer \& T. J. Krabbenhoft. 2010. A general hypothesis-testing framework for stable isotope ratios in ecological studies. Ecology, 91: 2227-2233.

Vander Zanden, M. J., J. M. Casselman \& J. B. Rasmussen. 1999. Stable isotopes evidence for the food web consequences of species invasions in lakes. Nature, 401: 464-467.

Vander Zanden, M. J., S. Chandra, B. C. Allen, J. E. Reuter \& C. R. Goldman. 2003. Historical food web structure and restoration of native aquatic communities in the Lake Tahoe (California-Nevada) basin. Ecosystems, 6: 274-288.

Vander Zanden, M. J. \& J. B. Rasmussen. 1999. Primary consumer $\delta^{13} \mathrm{C}$ and $\delta^{15} \mathrm{~N}$ and the trophic position of aquatic consumers. Ecology, 80: 1395-1404.

Wagner, C. E., P. B. McIntyre, K. S. Buels, D. M. Gilbert \& E. Michel. 2009. Diet predicts intestine length in Lake Tanganyika's cichlid fishes. Functional Ecology, 23: 11221131.

Welker, M. T., C. L. Pierce \& D. H. Wahl. 1994. Growth and survival of larval fishes: roles of competition and zooplankton abundance. Transactions of the American Fisheries Society, 123: 703-717.

Wurtsbaugh, W. \& H. Li. 1985. Diel migrations of a zooplanktivorous fish (Menidia beryllina) in relation to the distribution of its prey in a large eutrophic lake. Limnology and Oceanography, 30: 565-576.

Zambrano, L., E. Valiente \& M. J. Vander Zanden. 2010a. Food web overlap among native axolotl (Ambystoma mexicanum) and two exotic fishes: carp (Cyprinus carpio) and tilapia (Oreochromis niloticus) in Xochimilco, Mexico City. Biological Invasions, 12: 3061-3069.

Zambrano, L., E. Valiente \& M. J. Vander Zanden. 2010b. Stable isotope variation of a highly heterogenous shallow freshwater system. Hydrobiologia, 646: 327-336.

Submitted May 29, 2014 Accepted December 08, 2014 by Francisco Araújo Published June 30, 2015 
Appendix 1. Mean $\delta^{13} \mathrm{C}$ and $\delta^{15} \mathrm{~N}$ values (\%o) for members of the Lake Chapala food web. Table is arranged by collection site (Site No.). "n" is the number of samples for a group obtained per site. "SE" is standard error for individual samples in a site. "Type" refers to whether the sample is from an invertebrate (Invert) or a fish.

\begin{tabular}{|c|c|c|c|c|c|c|c|}
\hline Site No. & Taxa/Group & $\mathrm{n}$ & $\delta^{15} \mathrm{~N}$ & SE & $\delta^{13} \mathrm{C}$ & SE & Type \\
\hline 1 & Zooplankton & 1 & 15.18 & - & -30.12 & - & Invert \\
\hline 1 & Cambarellus chapalanus & 1 & 15.74 & - & -25.49 & - & Invert \\
\hline 1 & Oreochromis sp. & 1 & 16.57 & - & -28.03 & - & Fish \\
\hline 1 & Chirostoma consocium & 6 & 18.01 & 0.16 & -25.58 & 0.20 & Fish \\
\hline 1 & Chirostoma jordani & 1 & 17.20 & - & -25.93 & - & Fish \\
\hline 1 & Chirostoma labarcae & 6 & 17.62 & 0.38 & -25.35 & 0.29 & Fish \\
\hline 1 & Chirostoma promelas & 1 & 16.96 & - & -25.61 & - & Fish \\
\hline 2 & Zooplankton & 1 & 17.09 & - & -28.89 & - & Invert \\
\hline 2 & Chirostoma consocium & 5 & 17.84 & 0.32 & -25.42 & 0.22 & Fish \\
\hline 2 & Chirostoma labarcae & 6 & 17.9 & 0.25 & -25.10 & 0.13 & Fish \\
\hline 2 & Chirostoma promelas & 1 & 17.91 & - & -25.61 & - & Fish \\
\hline 3 & Zooplankton & 1 & 16.45 & - & -28.42 & - & Invert \\
\hline 3 & Cambarellus chapalanus & 1 & 16.66 & - & -24.96 & - & Invert \\
\hline 3 & Chapalichthys encaustus & 1 & 16.86 & - & -24.78 & - & Fish \\
\hline 3 & Chirostoma consocium & 6 & 17.4 & 0.14 & -25.49 & 0.18 & Fish \\
\hline 3 & Chirostoma jordani & 2 & 16.44 & 0.01 & -24.25 & 0.27 & Fish \\
\hline 3 & Chirostoma labarcae & 6 & 17.54 & 0.28 & -25.45 & 0.21 & Fish \\
\hline 3 & Chirostoma promelas & 5 & 17.92 & 0.12 & -25.26 & 0.15 & Fish \\
\hline 4 & Zooplankton & 1 & 16.26 & - & -27.36 & - & Invert \\
\hline 4 & Chirostoma consocium & 6 & 17.62 & 0.11 & -25.10 & 0.29 & Fish \\
\hline 4 & Chirostoma jordani & 2 & 16.73 & 0.23 & -25.80 & 0.00 & Fish \\
\hline 4 & Chirostoma labarcae & 6 & 16.76 & 0.30 & -24.90 & 0.20 & Fish \\
\hline 4 & Chirostoma promelas & 3 & 17.69 & 0.09 & -25.38 & 0.23 & Fish \\
\hline 5 & Zooplankton & 1 & 14.05 & - & -28.05 & - & Invert \\
\hline 5 & Cambarellus chapalanus & 1 & 16.91 & - & -25.14 & - & Invert \\
\hline 5 & Oreochromis sp. & 1 & 17.9 & - & -25.54 & - & Fish \\
\hline 5 & Chirostoma consocium & 6 & 17.76 & 0.17 & -25.81 & 0.21 & Fish \\
\hline 5 & Chirostoma jordani & 6 & 17.33 & 0.10 & -25.32 & 0.13 & Fish \\
\hline 5 & Chirostoma labarcae & 5 & 17.24 & 0.21 & -25.39 & 0.32 & Fish \\
\hline 6 & Chirostoma consocium & 4 & 18.04 & 0.38 & -25.98 & 0.21 & Fish \\
\hline 6 & Chirostoma jordani & 1 & 17.91 & - & -25.95 & - & Fish \\
\hline 6 & Chirostoma labarcae & 6 & 17.98 & 0.22 & -25.59 & 0.08 & Fish \\
\hline 6 & Chirostoma promelas & 1 & 19.53 & - & -25.53 & - & Fish \\
\hline 7 & Zooplankton & 1 & 14.60 & - & -28.38 & - & Invert \\
\hline 7 & Chirostoma consocium & 6 & 18.19 & 0.31 & -25.55 & 0.22 & Fish \\
\hline 7 & Chirostoma labarcae & 5 & 18.04 & 0.17 & -25.73 & 0.16 & Fish \\
\hline 7 & Chirostoma promelas & 4 & 18.15 & 0.11 & -25.49 & 0.17 & Fish \\
\hline 8 & Pseudotelphusa sp. & 4 & 13.40 & 0.30 & -18.66 & 0.22 & Invert \\
\hline 8 & Hidurinea & 1 & 16.22 & - & -20.19 & - & Invert \\
\hline 8 & Hyallela sp. & 1 & 11.84 & - & -19.03 & - & Invert \\
\hline 8 & Ephemeroptera & 1 & 11.99 & - & -19.27 & - & Invert \\
\hline 9 & Chirostoma consocium & 2 & 17.24 & 0.87 & -25.93 & 1.13 & Fish \\
\hline 9 & Chirostoma jordani & 3 & 17.27 & 0.03 & -25.05 & 0.21 & Fish \\
\hline 10 & Chapalichthys encaustus & 1 & 17.58 & - & -24.50 & - & Fish \\
\hline 10 & Goodea atripinnis & 3 & 15.16 & 0.56 & -25.31 & 0.72 & Fish \\
\hline 10 & Lepomis macrochirus & 2 & 16.47 & 1.00 & -24.67 & 0.35 & Fish \\
\hline 10 & Poecilia sphenops & 4 & 14.80 & 0.58 & -20.88 & 1.11 & Fish \\
\hline 10 & Oreochromis sp. & 4 & 13.53 & 0.50 & -25.71 & 1.67 & Fish \\
\hline 10 & Chirostoma consocium & 2 & 17.27 & 0.07 & -25.06 & 0.08 & Fish \\
\hline 10 & Chirostoma jordani & 2 & 17.64 & 0.32 & -25.3 & 0.49 & Fish \\
\hline 10 & Chirostoma labarcae & 2 & 17.59 & 0.50 & -25.45 & 0.16 & Fish \\
\hline 11 & Chirostoma sphyraena & 2 & 18.67 & 1.24 & -25.30 & 0.91 & Fish \\
\hline 12 & Bivalvia & 2 & 12.03 & 0.72 & -24.65 & 0.26 & Invert \\
\hline
\end{tabular}

